AUTHOR CORRECTION

\title{
Author Correction: Non-local effect of impurity states on the exchange coupling mechanism in magnetic topological insulators
}

Thiago R. F. Peixoto (iD), Hendrik Bentmann, Philipp Rüßmann (D), Abdul-Vakhab Tcakaev (iD, Martin Winnerlein, Steffen Schreyeck, Sonja Schatz, Raphael Crespo Vidal, Fabian Stier (D), Volodymyr Zabolotnyy, Robert J. Green, Chul Hee Min, Celso I. Fornari, Henriette Maaß, Hari Babu Vasili, Pierluigi Gargiani, Manuel Valvidares (iD, Alessandro Barla (iD, Jens Buck, Moritz Hoesch (iD), Florian Diekmann, Sebastian Rohlf, Matthias Kalläne, Kai Rossnagel (D), Charles Gould, Karl Brunner, Stefan Blügel, Vladimir Hinkov (D), Laurens W. Molenkamp and Friedrich Reinert

npj Quantum Materials (2021)6:14; https://doi.org/10.1038/s41535-021-00314-9

Correction to: npj Quantum Materials https://doi.org/10.1038/ s41535-020-00288-0, published online 19 November 2020.

The original version of this Article contains an error in the project i.d. in Acknowledgements, which originally incorrectly read "ct.qmat (EXC 2147, project-id 39085490)", rather than the correct "ct.qmat (EXC 2147, project-id 390858490)".

This has now been corrected in both the PDF and HTML versions of the Article.

\begin{abstract}
(c) Open Access This article is licensed under a Creative Commons Attribution 4.0 International License, which permits use, sharing, adaptation, distribution and reproduction in any medium or format, as long as you give appropriate credit to the original author(s) and the source, provide a link to the Creative Commons license, and indicate if changes were made. The images or other third party material in this article are included in the article's Creative Commons license, unless indicated otherwise in a credit line to the material. If material is not included in the article's Creative Commons license and your intended use is not permitted by statutory regulation or exceeds the permitted use, you will need to obtain permission directly from the copyright holder. To view a copy of this license, visit http://creativecommons.org/licenses/by/4.0/.
\end{abstract}

(c) The Author(s) 2021 